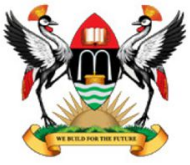

East African School of

Higher Education Studies \& Development

\title{
Revamping Technical Vocational Education and Training through Public-Private Partnerships for Skill Development
}

\author{
Jane Itohan Oviawe ${ }^{1}$ \\ ${ }^{1}$ Department of Vocational and Technical Education, Ambrose Alli University, Ekpoma [E-mail: \\ janeoviawe@yahoo.com ]
}

\begin{abstract}
Technical Vocational Education and Training (TVET) faces huge demands globally due to the high level of unemployment and the quest for technological development, industrialization and economic growth. For TVET to achieve its objectives of enabling leaners to catch up with the ever-changing living standard in a fast growing technological world and creating jobs for sustainable living, it must be strengthened through public-private partnerships (PPP) because government cannot singlehandedly shoulder this enormous task. It is with this understanding that this paper examined the need for PPP in TVET, strategic issues for TVET in Africa, reforms in TVET, PPP models for skill development and ways of revamping TVET through PPP. The paper suggests that PPPs should be encouraged. Sharing of tools and equipment between TVET institutions and industries - aimed at ensuring that learners are abreast with developments in the world of work - is also recommended.
\end{abstract}

Keywords: TVET; Public-private partnerships; Employment.

\section{$1 \quad$ Introduction}

Technical Vocational Education and Training (TVET) is globally recognized for its role in preparing people for dynamic engagement in occupations of functional value and effective source of skilled workforce. The United Nations Educational Scientific and Cultural Organization (UNESCO) and the International Labour Organization (ILO) recommendation of 2000 on TVET for the $21^{\text {st }}$ century define TVET as: (i) an integral part of general education; (ii) a means of preparing for occupational fields and effective participation in the world of work; (iii) an aspect of lifelong learning and a preparation for responsible citizenship; (iv) an instrument for promoting environmentally sound sustainable development; (v) a method of facilitating poverty alleviation (Oviawe, Uwameiye \& Uddin, 2017). Similarly, UNESCO (2009) defined TVET as all forms and aspects of education 
that are technical and vocational in nature, provided either in educational institutions or under their authority, by public authorities, the private sector or through other forms of organized education, formal or non-formal, aiming to ensure that all members of the community have access to the pathways of lifelong learning. The above definitions of TVET implies that its goal is to fight ignorance and literacy, provide knowledge, develop skills and inculcate the attitudes that are required for entry and progressing in any occupation. To Kukoyi (2009), TVET is a planned programme of courses and learning experiences that begin with exploration of career options, support basic academic and life skills, and enable achievement of high academic standards, leadership and preparation for industry-defined work. This implies that TVET prepares learners for career that are based on manual or practical activities, traditionally non-academic and totally related to a specific trade, occupation or vocation. Unlike general education, learning in TVET is centred on 'applied' as opposed to 'academic', practical as opposed to theory, and skills as opposed to knowledge. Accordingly, TVET today face huge demands globally due to high level of unemployment. For TVET to achieve its envisaged objectives, it must be properly strengthened. Government alone cannot shoulder this enormous task hence the need for TVET and public/private collaboration. This paper therefore examined how public/private partnership or collaboration could be employed for strengthening workplace training in TVET.

\subsection{Concepts of Public/Private Partnership and TVET}

The private sector is the part of a country's economic system that is run by individuals and companies, rather than the government. Most private sector organizations are run with the intention of making profit. An easier way to think of the private sector is by thinking of organizations that are not owned or operated by the government. The public sector is owned and controlled by national, state and local governments. The differences between public and private sectors include the following: (i) the public sector is made up of agencies and institutions owned and operated by the government, while the private sector is made up of small businesses, corporations, as well as profit and non-profit organizations; (ii) the public sector is not profit driven, while this is the case with the private sector; (iii) the end beneficiary of the services offered by the public sector is the general public, while it is the general consuming public who take advantage of the goods and services offered for profit by the private sector businesses.

The alliance between TVET and public/private sector is referred to as partnership. A partnership is an agreement where parties or partners agree to cooperate to advance their mutual interests. This agreement could be between government, schools, employers, professional associations, employees and their representatives, the local community and combinations of organizations. TVET 
institutions can partner with public/private sector to extend their frontiers in form of Public-Private Partnership (PPP).

The PPP Policy (2012) defined Public-Private Partnership as a long-term procurement contract between the public and private sectors in which the proficiency of each party is focused in the designing, financing, building and operating an infrastructure, project or providing services through the appropriate sharing of resources, risks and rewards. Maigida (2014) defined public private partnership as a joint mutual agreement entered into by the government and private bodies to provide services to people based on established terms. Similarly, Agence Francaise De Development (AFD) (2014) viewed publicprivate partnership as that consisting of bringing together public authorities and private stakeholders to devise, finance, build, manage or preserve a project of public interest. PPP is a generic term for the relationships formed between the private sector and public bodies often with the aim of introducing private sector resources and/or expertise in order to help provide and deliver public sector assets and services. Contextually, PPP in TVET refers to various agreements between the public and private sector partners by which the private sector partners delivers infrastructures and services that should have been provided by the public sector without comprising the profit objectives of the private partners, the primary aim of which is to provide opportunities for practical training of learners for skill development. According to Piyasiri, Suraweera \& Edirinsootiya (2008), there are two types of Partnership. These are the formal partnership which obtains where each party's role and obligations are spelt out in a written agreement and informal partnership where the roles and obligations are agreed verbally. The essential characteristics of PPP according to PPP Policy (2012) are:

1. Involve an arrangement with a private sector entity by delegating one or more project functions to them (that is delegating to a private party the responsibility to design, build, or expand/develop, operate, maintain, rehabilitate, or finance an asset or service);

2. Require a private party to take significant risk in performance of functions delegated - that is, the private party's revenue is dependent on its performance (the availability of an asset, or the quantity and quality of outputs supplied);

3. Involve public infrastructure/asset or service provided for public benefit where the output has the element of facilities/services being provided by the government as a sovereign to its people; and

4. Operations or management of the asset or service is within specified period. The agreement with the private sector entity has the element of a time period after which the arrangement comes to a closure. Hence, the arrangement is not in perpetuity. 


\subsection{Need for Public/Private Partnership in TVET}

The unfortunate neglect of TVET is an obstacle to national and global development. Governments globally have sought to address the issue of unemployment. The number of unemployed graduates and youths in the labour market is alarming but more alarming and disturbing is the quality of these graduates. Unemployment has bedevilled the lives of people causing untold hardship, suffering, dejection, frustration among others. The high rate of unemployment among youths has contributed to the high rate of poverty and social vices. The excerpts of statistics obtained from the National Manpower Board and Federal Bureau of Statistics that Nigeria has a youth population of 80 million representing $60 \%$ of her total population. 64 million of them are unemployed while 1.6 million are under-employed whereas about 112.5 million Nigerians live below the poverty line (National Bureau of Statistics, 2015).

TVET according to Australian National Training Authority (ANTA) (2003), is no longer seen as being solely in the realm of educational institutions but is increasingly involving workplaces, private individuals and a variety of other nongovernmental and community organizations. ANTA stated that the increasingly competitive changes in the nature of the economy as well as occupational and workplace changes have had a significant impact on the nature of the workplace. This implies that the skill level of present ad prospective employees must be continuously developed. As such, workplace learning (both formal and informal) is taking on an increasingly important role in the education and training of the workforce. Hence, there is need for collaboration.

The need for PPP in TVET is also justified by the fact that TVET institutions and their programmes are ineffective and of low quality. There are a lot of challenges facing TVET in Africa the greatest of which is inadequate funding by the governments. In addition, infrastructures in most schools, including higher institutions are dilapidated. Moreover, there is an adverse learning condition characterized by paucity of teaching and instructional materials, absence of adequate infrastructures in most TVET institutions. Okeshola (2012) stated that the hygiene and sanitary conditions in most TVET institutions are also critical and this has been identified as a contributory factor to the poor retention and participation of girls in TVET.

Research evidences indicate the following as challenges facing TVET: most formal TVET institutions are currently operating in an environment that is characterized by low quality training and mismatch between training and labour market skill demand (Yusuf \& Soyemi, 2012); the quality of TVET facilities like workshops, books, classrooms, learning environment, machines, computer rooms, TV/Audio visual, instructors and contents of curriculum are inadequate in most tertiary institutions (Akhuemonkhan \& Raimi, 2013); inadequate classroom blocks, lack of conducive staff offices, inadequate electricity supply, 
lack of water supply, inadequate workshop spaces, lack of TVET machines and tools, lack of TVET books, lack of consumable materials and inadequate instructional materials (Ayonmike, Okwelle \& Okeke, 2013).

The obvious implication of these challenges is that the quality of training given to the learners is very low and they may end up not acquiring adequate skills required for getting and sustaining employment in the labour market or being self-reliant. In view of these issues, PPP has become necessary for the following reasons: the widening infrastructure gap, increased demand for TVET, inadequate government funding, inadequate facilities and falling standard of education. PPP is inevitable due to the growing economic and financial difficulties which have made it impossible for many governments to pay for the rather high cost of TVET (Okoye \& Chijioke, 2013).

\section{Strategic issues for PPP in TVET in Africa}

In spite of the sterling position of TVET in the socio-economic transformation globally, it has suffered neglect for too long in Africa. UNESCO (2009) stated that as promising as the potentials of TVET are, it is however, estimated that only $10 \%$ of secondary school students worldwide are enrolled in school-based TVET programmes when considered from the standpoint of enrolment, manpower, facilities and funding. In order TVET to achieve the desired capacity building and sustainable development, the following challenges and issues must be addressed:

\subsection{Enrolment}

According to UNESCO Institute of Statistics (2006), African countries can be grouped into three categories when judged on the basis of percentage enrolment of TVET institutions against the total enrolment of conventional secondary school programmes in 2005. The first group of 10 countries according to the ranking scores included Rwanda (34\%), Cameroon, Democratic Republic of Congo, Egypt, Libya, Congo, Mauritius, Benin, Algeria and Mali all with a percentage of vocational/technical schools enrolment to conventional secondary schools' enrolment up to $10 \%$ or more. The second group had a proportion of vocational/technical schools' enrolment to general secondary education enrolment between $5 \%$ and $9 \%$. These groups of countries include Burkina-Faso, Burundi, Djibouti, Mozambique, and Tunisia, 8\% each, Botswana, Morocco, South Africa, Cape-Verde, and Togo 5\% each. The third group of countries had percentage enrolment in technical/vocational schools of the total students of secondary school programmes less than 5\%. These countries included Mauritania (4\%), Uganda (4\%), Niger, Ethiopia, Ghana, Guinea-Bissau, Zambia, Chad, 
Eritrea, Gambia, Kenya, Lesotho, Sao-tome, Senegal and Sudan, 1\% each. It is disheartening to find that Nigeria did not feature in any of these three categories, implying that her enrolment was less than $1 \%$. The long proportion of students enrolled in TVET programmes signals stagnation and overall poor public training capacity. TVET has failed to absorb many school leavers who would have had opportunities to make useful contributions to the development of the society.

\subsection{Public Perception}

Generally, technical and vocational education has been perceived as a career path for the less academically endowed. This has been fuelled partly by the low academic requirements for admission into TVET programmes and the limited prospects for further education and professional development (African Union, 2001). Similarly, TVET personnel tend to show low self-esteem in social relations due to devalued status accorded TVET. Universally, nations have identified this neglect and devalued esteem. To this end, Ruqayata Rufai, a Nigerian former Minister for Education frowning at the poor public perception asserted that one crucial challenge affecting TVET is low societal estimation of TVET. Bo (2012) commenting on the situation in China posited that for a long time, even today, TVET is regarded as a sub-class or lower rank education. This negative mind set can be changed through intensive public enlightenment that TVET is an effective programme to train skilled workers for the employment market and sustainable livelihood.

\subsection{Attitude towards Implementing TVET Policies}

TVET programmes need to play a pivotal role in developing a new generation of people who will face the challenges of achieving sustainable socio-economic development throughout the globe (UNESCO, 2001). The major issue facing TVET implementation is the lack or unsatisfactory policy framework, and therefore stated that good policy framework will help promote TVET and its curriculum design and delivery to meet the needs of the labour market. There is need to revise the school's curriculum to reflect multiple intelligent from the industrial sector. To ensure that the issue of policy framework in TVET is addressed, publicity and advocacy for new TVET policy can serve as a means for proper implementation of TVET programmes. Since policy framework is the driving force to the planning, implantation and attainment of any programme or organizational objectives, therefore a good TVET policy framework can help to monitor and control manpower development for the workplace.

\section{$2.4 \quad$ Skilled Manpower}

The delivery of quality TVET is dependent on the competence of the instructors. Most instructors possess the theoretical knowledge but lack the technical and 
practical skills. Also instructors may not be abreast with new technologies in the workplace. This leads to the production of graduates who lack the saleable skills and competences required by employers of labour. These dampen the interest the interest of investors in TVET. But the situation could be better if the PPP is fully encouraged.

\subsection{Relating TVET to Priority Areas of the Country}

It is important to identify priorities of a nation before coming out with innovation areas that would contribute to the rapid development of the nation. TVET institutions should fashion its training in harmony with identified priorities of the country. A study by the African Union on the state of TVET in 18 African nations has shown the priority areas for vocational training in Africa in the following order: agriculture, public health, water resources, energy, environmental management, information and communication technology, construction and maintenance.

The general recommendation from the states include the development of appropriate competency-based curriculum in these areas, and compulsory implementation of TVET programmes for students in strategic fields such as entrepreneurship, computer literacy, agriculture and building construction. Training without consideration to priority areas will certainly result in flooding the workplace with unwanted skills thereby raising the level of unemployment and under-employment.

\subsection{Linking TVET with Traditional Skills}

Traditional skills have served tremendously in providing a source of livelihood. Some of these have been abandoned in quest for foreign skills. Where foreign skills can no long suffice due to lack of raw materials and where there is plenty of raw materials, TVET programmes can inject innovation into local skills for the production of traditional artefacts and related crafts to safeguard them from being extinct and to provide sustainable living.

\subsection{Funding of TVET}

Funding is an absolutely crucial input of any educational system. It provides the essential purchasing power with which education acquires its human and material resources. It is difficult to talk of the relevance and quality of education without considering the issue of funding and indeed, the funding process. TVET has suffered in the hands of general education administrators who in many nations have control over funds especially when such funds are centrally controlled, and where TVET is jointly managed with general education. In the situation where 
the two are jointly managed the likely personnel in control, for obvious reasons, is the general educator who hardly understands that TVET is much more capital intensive and more financially demanding than general education. A way out is to separate the management of TVET from that of general education. In Nigeria, the establishment of the National Board for Technical Education (NBTE) and TVET boards at the State level has to an extent addressed the management issues. However, a lot still need to be done by ensuring that only professional TVET managers and policy makers with adequate expertise and insight be placed in control of TVET.

\subsection{Training Facilities}

Training for high quality skills requires appropriate equipment and tools, adequate supply of training materials and consistent practice by the learners. For result-oriented training, tools, equipment and other required facilities must be a replica of what is obtainable in the workplace where the trainees are expected to work upon graduation. There is little or no infrastructure and future positive policies out on ground by the government for TVET scholars and graduates. This is challenge as the private/public sectors do not have anything on discussion to consolidate on, hence most interested investors are discouraged.

\subsection{Quality Assurance and Certification in TVET}

TVET staff in many countries lack technical capacity to develop national qualifications courses, competency-based curriculum and training packages as well as quality assurance and accreditation standards in TVET (African Union, 2007). This situation gives rise to inconsistency in quality control and certification of TVET programmes. In Nigeria, the chief executives of National Directorate of Employment (NDE) and the NBTE jointly noted that the noncertification of programmes in government's vocational centres across the nation had been identified as a factor against high rate of people's enrolment in the centres (NBTE, 2013). The Federal Republic of Nigeria in 2013 approved a sixlevel National Vocational qualification framework that recognizes and certifies skills and vocations outside the school system and places same on the schemes of service (NBTE, 2013). It is worthy to note that a sound certification system is predicted on the quality of training. This means that the popularity and acceptability of a certificate is dependent on the extent to which its holders acquit themselves or show quality in their post-certification endeavours. To this end, NBTE (2013) posited that for each level of training, trainees should acquire necessary skills and show adequate knowledge of theoretical principles in their respective trades before certification. 
City and Guilds Certificate of London Institute has been able to gain wide acceptability globally because of its sound quality assurance indices. Established in 1878, City and Guilds till date has developed qualifications across a variety of sectors that meet the needs of the $21^{\text {st }}$ century's workplace and it works with over 10,000 centres and training providers in 80 countries around the world, offering more than 500 qualifications across 28 countries (MCS Consulting Ltd, 2012).

\subsection{Training for Skills, Job-Creation and Linking TVET Institutions to the Workplace}

Developing relevant skills and matching training with job for sustainable living is fundamental to effective TVET. This objective can be achieved if TVET know the needs the workplace requires from TVET products or graduates. These needs may include: practical capacity (capacity for skill acquisition); theoretical and technical knowledge (capacity to show knowledge of operating principles and relate to practice); creativity and entrepreneurship, social capacity, and information and communication technology (ICT) skills (Madungwa, 2012). Other skills required by the workplace include communicative skills; critical thinking and problem Solving skills; team work; long learning and information management skills; entrepreneurship skills; ethics, moral and professional; and leadership skills.

TVET institutions cannot successfully play this role of providing high quality manpower with advanced skills if it operates in isolation of the operating industries that require skilled workers. TVET institutions must establish collaborative linkages with these industries that require their graduates. Such linkages on a well fashioned partnership terms will guarantee quality skill and smooth transition from school to work. In meeting, the skill needs of the teeming youths and addressing ever-increasing trend of unemployment and underemployment, government globally have been compelled to strengthen the link between institutions and workplace. This in most cases takes the form of closely involving the industry and, developing occupational standards and, workbased verification and continuous assessment of trainees.

The world needs a production-oriented TVET which must incorporate functional skill development and knowledge driven programmes with sufficient motivational and reward mechanism. For TVET to produce people with powerful skills and high quality innovative minds to build the world and make it a better place, some fundamental mechanisms such as TVET institution-workplace collaboration should be considered. 


\section{Reforms in TVET}

The fast pace of development recorded in some nations such as Malaysia, Indonesia, Brazil, Canada, United States of America, Singapore, among others have revealed that development is driven by innovativeness, creativity and enterprise of the people. According to Maclean \& Wilson (2009), today, almost all nations have modernized their education and training system in order to ensure adequate supply of highly skilled workers.

In the United States of America, the reform began with an open letter to the American people entitled 'A nation at risk: the imperative for educational reforms'. Strategies were to arrest America's workforce crises. Canada used a two-pronged innovation strategy. The first focused on creating and using knowledge as national asset while the second called for investment in people as a country's most important resource. Australia owes its success to investment initiatives and to successive and repeated commitment to TVET demonstrated through various policies, planning and investment initiatives formulated in the key national development plans. The European Union focuses on linking TVET to productivity, employment and social cohesion.

Singapore progressively focuses its TVET principally on her three phases of economic development: 'Factor-Driven' economy (1960s-1970s) which involved intensive labour; 'Investment-Driven' economy (1980s-1990s) which was capital intensive; and 'Innovative-Driven' economy (2000s) being powered by the needs of knowledge for intensive industrialization as well as continuous and heavy investment. The African Union recognizes TVET as a means of empowering individuals to take control of their lives and recommends integration of vocational training into the general education system.

Malaysia utilizes Private Partnership Participation (PPP) approach to revamp its TVET. Strategies employed involve the setting up of National Dual Training System (NDTS); Human Resources Development Fund (HRDF) and Vocationalisation of Tertiary Institution. There is a Training Reimbursement Scheme. The companies that participate in certain apprentice training programmes qualify for tax incentives and $1 \%$ part of the training cost from government. These incentives stimulate healthy competition and better performance among the training companies. Of vital importance, the students/apprentices are: (i) assured of employment; (ii) eligible for total reimbursement of training cost; and (iii) given insurance protection among others.

The PPP approach employed by Malaysia accelerates industrial training, and offers opportunities for industries and public/private TVET institution to contribute to relevant and more responsive skill development. Malaysia came about this approach through recommendations made by a task force set up to 
suggest strategies for revamping TVET. The task force based their recommendations on models found in TVET institution in Germany, Hong Kong and other countries. Maigida (2014) advanced the following as reasons for the needs of PPP in TVET:

1. High cost of providing infrastructure for effective TVET programme.

2. Most countries of the world have not realized that the state alone cannot provide the needed access to high quality infrastructure and skill training.

3. Private sector involvement whether at provision of infrastructure or at the level of training delivery can greatly enhance what the state affords.

Similarly, Ndagi (2010) highlighted the following as the reasons government adopts the PPP model:

1. PPP enhances governments' capacity to develop integrated solutions to infrastructure provisions, decline decay.

2. It facilitates creative, innovative, cost reducing and faster approaches to project implementation.

3. It enhances public management, improved quality services and generation of additional revenues.

4. It facilitates access to skills, experience and technology while enhancing transfer and acquisition of technical knowledge know-how.

5. It allows for transfer of risks which are inherent to project partners on agreed sharing formula.

Unfortunately, some African nations such as Nigeria have not been able to enact similar feats owing to poor linkage between knowledge and skill development, and among the private public sector of the economy. This according to Adeniyi (2012) may have been due to lack of appropriate TVET skills and insufficient entrepreneurial culture in the educational system. On TVET development in schools, UNESCO (2000) posited with regret that less than $1 \%$ of secondary education in Nigeria is oriented towards technical and vocational skills. The economic and technological development of any nation does not solely depend on the education population but to a large extent on skilled workforce that can handle the rapidly changing demands of the labour market. To boost economic development, revamp TVET and reduce unemployment, there is need for urgent private/public partnership collaboration for effective TVET skills acquisition programmes.

\section{$4 \quad$ Public-Private Partnership Models for Skill Development}

In seeking ways of bringing TVET institutions globally closer to real-life work experiences in industries, some conceptual models PPP of vocational education have been developed. These models include: 


\subsection{The Dual Vocational Training System}

The dual system exists in Germany, Switzerland and to a limited extent in Australia, Denmark, Norway, Luxemburg and the Netherlands. The German system of partnership (dual system) is one based on a law from 1969 that mandates a particular governance structure for TVET. At the heart of the German system is a delegation of responsibility for curriculum and assessment to a coalition of labour representatives, business and educators. The business plays a given complex role managing the system by monitoring the quality of training provided by firms in the dual system. Market Intelligence Germany (2014) stated that under this system of vocational training, trainees undergo 1-2 days training in the public training schools and 3-4 days training in companies. The dual system relies on the sharing of cost among companies and government. For instance, the schools are funded by government while companies pay remuneration to apprentices. The following components must be in place for proper application of the German model:

1. a legislative framework that requires firms to invest in training of newly hired workers;

2. a funding mechanism through a combination of federal, regional and business spending;

3. the capacity to carry out jobs analysis and curriculum development;

4. local institutions that represents the interest of business; and

5. trained professionals' instructions and administrators.

Euler (2013) listed the following as the essential elements of the German dual system:

1. it has broad objectives as vocational training is a means of achieving economic, social and individual goals;

2. the main objective of vocational training is to produce skilled workers with flexible qualifications who are mobile and capable of working in their chosen fields;

3. learning situations are alternated in accordance with the dual principle;

4. vocational training is a task to be carried out in partnership between the government and the business community

5. there is joint funding of vocational training by the government and private sector;

6. complementary programmes are run by schools or non-business entities;

7. quality standards are codified;

8. qualifications of teachers and training personnel is a very important factor; and

9. there is nationwide social acceptance of vocational training. 
TVET in a regular school setting focuses on students' practical exercises and test-production. The DUAL concept is a useful innovation. Dybowski (2005) summarized the main features of the German dual system as: TVET is organized by private and public sectors; conducted in companies and part-time vocational schools and carried out as training in the workplace and classroom tuition on the basis of training contract and compulsory attendance at vocational schools. It is regulated by government and supervised by chambers and school supervision bodies. In Nigeria, the National Board for Technical Education (NBTE) supports this approach by recommending that each technical college should have a production unit to support the training needs and boost commercial production of goods and services. In this approach, TVET institution is split into two major directorates, namely: (i) Directorate of training: to offer regular academic activities and skill training in a practicing workshop; and (ii) Directorate of commercial production: to produce goods and services in commercial quantity in a designated production workshop.

\subsection{The Japanese System}

This model is totally different from the German model, but relevant in the USA and other nations with social networks. This model is based on a local relationship and depends on high school staff correctly analysing the skills of potential graduates and their fit with academic and vocational needs of employers. Here, Japan's manufacturing system come from high schools, which have a network of relationships with hiring managers that allows them to place their most accomplished students preferentially. This model encourages government use of incentives such as tax levies to promote training.

\subsection{The Factory School Model in Singapore}

According to Tucker (2012), the model of VET system in Singapore is the factory school model that focuses on encouraging firm level training through government policy known as 'Human Resource Development' or 'Workforce Development System'. This model enables Singapore to train its workforce to truly state-of-the-art standards, to engage industry as a close partner in training, to enable students to train in an environment that is designed for training, but which, at the same time, is similar enough to the real thing to present challenges for the students very much like those they will face in the workplace. It combines the advantages of a first-rate apprenticeship system with the advantages of firstrate school-based VET system.

The factory school model is based on and designed to foster close link between the VET system and the industry, there is an apprenticeship system, 
faculty members in the school-based system are required to work periodically in a firm in the same field in which that person teaches, and students are also required to spend time working in firms. Similarly, employers are deeply involved in advisedly the various VET institutions and programmes as well as in setting occupational standards, in assessing candidates for diplomas, providing state-of-the-art equipment for instruction and in advising on broad programme direction (Tucker, 2012). Other countries that have this type of programme include: South Korea, and Malaysia. They evolved in East Asia largely as governments in the 1960s to 1980 s tried to strengthen economic growth through spending on both initial and further vocational training. The core of these Human Resources Development strategies is taxation policies that allow the governments to collect revenue from firms and then allow government to use these resources to train within their own companies.

\section{Benefits of Public/Private Partnership in TVET}

According to African Development Fund (ADF) (2006), the benefits of PPPs include:

1. Speedy, efficient cost effective delivery of training programmes.

2. Poverty reduction through human resources development.

3. Improved access to quality TVET in formal and non-formal training institutions.

4. Enhancement of employment-oriented skills for youths and adults.

5. Reduction in the rate of school dropout and their potentials harnessed through skill training centres.

6. Innovation and diversity in the provision of public services.

7. Other benefits include:

8. Provide ample opportunities for students to have better industrial experience

9. Facilitate effective acquisition of practical skills as the industries will provide adequate facilities and competent instructors for the training

10. Foster development of positive professional attitudes by the students

11. Ensure that TVET curricula and teaching methodologies are up to date and relevant to the needs of the industries

12. Enable teachers and trainees to have access to the latest technology and practices

13. Intractable problem of poor funding, inadequate facilities, incompetent teachers would be greatly minimized.

14. Enable TVET institutions to know the level and types of skills currently required in the workplace. This will assist to minimize mismatch between skill supply and skill demand 
15. Help in the setup and maintenance of National Qualification Frameworks.

16. Improve service delivery as both sectors will be allowed to do what they know best with improved cost effectiveness thus minimizing infrastructure decay

17. Private sector will be more involved in planning and implementation of TVET programmes

18. Improve the level of mutual information on the job market, making recruitment of school graduates more efficient.

\section{Revamping TVET through PPP for Skill Development}

TVET has been recognized by many countries globally for helping to develop a professionally skilled workforce vital to economic and technological development. Grunewald (2008) posited that the economic growth vital for a nation's development and combating poverty is impossible without private sector participation. Grunewald added that private enterprises play an essential role in creating jobs and income for society and individuals. Corroborating this view, Abubakar (2010) highlighted that repositioning and subsequently improvement of TVET targeted at development of technology and scientific innovations cannot be achieved by government alone but it has to be in collaboration or partnership with private enterprises that have the technical expertise, vocational competencies and financial capability.

In revamping TVET, the private sector intervention may include technology support in terms of training and retraining of staff and students, provision of capital and expertise through participation in curriculum development, networks, and access to modern production equipment, tools, machines and technical know-how. The Organization for Economic Cooperation and Development (OECD) (2013) opined that the private sector can organize workplace leaning through internships, apprenticeship, cooperative education and continuing education and training (CET) schemes. OECD added that in internship, students go to work in enterprises in their expected career with little or no compensation for a period ranging from a few weeks to several months. Internships provide real world experiences to those who need to explore or gain the relevant knowledge and skills required to enter into a particular career (Olaitan, Nwachukwu, Igbo, Onyemachi \& Ekong, 1999). Grunewald (2008) listed the following as the key areas of collaboration between TVET institutions and the private sector:

1. Identifying training needs of technical staff;

2. Setting standards for the vocational and technical educators;

3. Developing training programmes/syllabi for TVET institutions;

4. Training and retraining of technical teachers and workshop attendants; 
5. Developing teaching and learning materials;

6. Qualifying and supplying teachers and instructors;

7. Planning and implementing training measure;

8. Setting up and implementing testing and examination systems;

9. Evaluating the relevance, significance, effectiveness and efficiency as well as impact of training measures and related activities; and

10. Financing activities.

It is expected that the collaboration between TVET institutions (Government) and the private sector will result in efficient delivery of services (skill development) due to the private sector endowment in financial resources, technology, technical know-how and others, whereas the public sector has strong policies to guide the private sector; therefore, the combination will be overwhelming and tremendous.

\section{$7 \quad$ Conclusion and Recommendations}

TVET is essential because it creates job for sustainable living and provides training that individuals require to catch up with the dynamic and ever-changing living standard in a fast growing technological world. TVET is a training that any nation requires to foster its socio-economic development. The UNESCO and ILO intervention with relevant recommendations has in recent times compelled thorough-going reforms globally towards revamping TVET for sustainable skill development. What countries need mostly is how to successfully enforce implementation of their policy initiatives to make TVET effective through skill development towards reducing unemployment. This requires revamping TVET through PPP, making huge investment, showing repeated commitment to the cause of TVET and for TVET to gain proper public image. This paper examined TVET public private sector partnership in relation to conceptual issues. The need for public private partnership in TVET, strategic issues for TVET in Africa, reforms in TVET, PPP models for skill development, benefits of PPP in TVET and ways of revamping TVET through PPP for skill development.

Based on the literature reviewed in this paper, the following recommendations are suggested:

1. TVET private sector partnership should be encouraged, so as to ensure effective development training programme necessary for acquisition of new technologies by TVET recipients towards causing a home-grown industrial revolution like other developed nations. The sharing of tools and equipment between TVET institutions and industries will help the students keep abreast the changes taking place in the world of work. 
2. There should be period staff and student exchange programme between TVET institutions and the workplace to equip students and staff with the practical skills while the workplace benefit from the theoretical knowledge of the staff and students of TVET

3. TVET private sector partnership should be encouraged in order to address the rising rate and poverty among youths in Africa.

4. There should be collaboration between TVET institutions and the workplace during curriculum development to address the needs of the industries.

\section{References}

Abubakar, M.S. (2010). Revitalizing TVET for technology entrepreneurship and industrial development: Measure, design and applicability. A paper presented at the national centre for technology. June 6th -8th.

Adeniyi, B. A. (2012). The role of entrepreneurship education in vocational and technical education. Adeniyi Agricultural Consult. The Punch Newspaper, Friday 12, 64-65.

African Development Fund (2006). African Union (2007). Strategies to revitalize technical and vocational education and training (TVET) in Africa: Final draft. Retrieved 22/8/2016 from http://www.africa.union.

Agence Francaise De Development (2014). Public-Private Partnership in vocational training: Taking stock of AFD's experience and strategic recommendations. Retrieved on 8/10/2017 from www.afd.org.

Akhuemonkhan, I. A. \& Raimi, L. (2013). Impact of quality assurance on technical vocational education and training (TVET) in Nigeria. Retrieved on $7 / 10 / 2017$

from www.iveta.org/Resources/Documents/about/.../Akhuemonkhan.pptx.

Australian National Training Authority 92003). What makes for good workplace learning? Retrieved on 7/10/2017 from http://www.ncver.edu.au.

Ayonmike, S.C. Okwelle, P.C. \& Okeke, B.C. (2013). Towards quality technical and vocational education and training programmes in Nigeria: Challenges and improvement strategies. Retrieved on 7/10/2017 from www.iveta.org/Resources?Documents/about/.../Ayomike./pptx.

Bo, Jiang (2012). China's TVET: Reform. An opening-up speech at the WF CP 2012 World Congress Halifax, Canada.

Dybowski, G. (2005). The dual vocational education and training system in Germany. Retrieved on 4/10/2017 from www.bibb.de/en.

Euler, D. (2013). Germany's dual vocational training system: A model for other countries. Retrieved on 4/10/2017 from www.bertelsmann-stiflung.de. 
European Centre for the Development of Vocational Training (2011). Learning while working: Success stories of workplace learning in nine countries. Retrieved on 4/10/2017 from www.cedefop.org.

Grunewald, E. (2008).PPP models in TVET and their impact on the role of Government. Journal of Association for the Development of Education in African.

Kukoyi, D. (2009). Design and implementation of Public-Private Partnerships in Education. Case study of Technical and Vocational Education.

Maclean, R. \& Wilson, D. (2009). International handbook of education for the changing world of work. International Centre for Education: UNESCOUNEVOC: University of Toronto. 81-96.

Madungwa, A. (2012). Achieving better teaching and learning in TVET. Paris: UNESCO.

Maigida, J.F. (2014). Building and sustaining partnership through public private partnership for effective technical vocational education and training programme in Nigeria. A paper presented at the 2014 annual international conference of International Vocational Education Association (IVETA) at Tennessee, USA. November 18-19. Retrieved on 2/6/2015 from www.iveta.org/.../Dr.J.F.Maigida.

Market Intelligence Germany (2014). Vocational Training "Made in Germany". Retrieved on 1/2/2015 from http://www.gtal.com.

MCS Consulting Ltd (2012). Mcsonsultingltd.com/index/html. Retrieved on 21/7/16 National Bureau of Statistics (2013). Poverty in Nigeria- World Bank Report. Retrieved on 15 th $/ 8 / 2016$ from http://www.nigeriapoliticsonline.com/poverty.

National Board for Technical Education (2013). Vocational Enterprise Institutions (VELs) and Innovative Enterprise Institutions (IELs). Retrieved on 12/10/2014 from www.Note.gov.ng/iei\&vei.html.

Ndagi, A. (2010). Understanding Public-Private Partnership in TVET development for technology and scientific innovation. A paper presented at the National workshop of National Centre for Technology Management in Minna, held between $16^{\text {th }}$ and 18 th June.

Okeshola, F. B. (2012).challenges facing realization of millennium development goals (MDGs) in educational reform in Nigeria. European Scientific Journal 8 (2), 201-205.

Okoye, K.R.E. \& Chijioke, O.P. (2013). Private-Public partnership and technical vocational education (TVET) in a developing economy. Arabian Journal of Business and Management Review 2(10), 51-61.

Organization for Economic Cooperation and Development (2013). Enhancing skills through public-private partnerships in Kazakhstan's information technology sector. Retrieved on 4/10/2016 from www.oecd.org/. 
Oviawe, J.I., Uwameiye, R. \& Uddin, P.S.O. (2017). Bridging skill gap to meet Technical, Vocational Education and Training school-workplace collaboration in the 21 st century. International Journal of vocational education and training research. 3 (1), 7-14.

Piyasiri, T.A., Suraweera, B.H. \& Edirinsootiya, M.L.N.S. (2008). Research studies on tertiary education sector. National Education Sector, Sri Lanka.

The PPP Policy (2012). Shaping new partnership for national development and institutional framework for the implementation of a public-Private Partnership programme for the government of Jamaica. Retrieved on 17/10/2016 fromhttp://www.dbankjm.com/files/public-private-partnership

Tucker, M.S. (2012). The phoenix: Vocational education and training in Singapore. Retrieved on 12/8/2016 from www.ncee.org/cieb.

UNESCO (2001). Revised recommendation concerning technical and vocational education. Paris: UNESCO.

UNESCO (2009). Regional contribution to Statistical Information Systems Development for Technical and Vocational Education and Training. Retrieved on 14th May, 2015 from http://unesdoc.unesco.org/images/0021/002160/216065e.pdf.

Yusuf, M.A. \& Soyemi, J. (2012). Achieving sustainable economic development in Nigeria through technical and vocational education and training: The missing link. International Journal of Academic Research in Business and Social Sciences 2(2), 71-77. 